\title{
Challenges and Opportunities of Shale Gas Extraction via Hydraulic Fracturing
}

\author{
Guy Francis Mongelli*
}

Department of Chemical Engineering, Case Western Reserve University, 10900 Euclid Ave. Cleveland, $\mathrm{OH} 44106$, USA

\section{Review Article}

Received: 25/04/2018

Accepted: 09/06/2018

Published: 18/06/2018

\section{*For Correspondence}

Guy Francis Mongelli, Department of Chemical Engineering, University of Rochester, 500 Wilson Blvd, Rochester, NY, 14627, USA, Tel: 6462095456

Email: gmongell@u.rochester.edu

Keywords: Shale gas, Impermeable rock

\begin{abstract}
Hydraulic fracturing, or fracking, is a technique used to excavate natural gas and oil trapped within porous layers of shale thousands of feet below the surface. The process stands to provide enormous benefits to the United States as a means of harvesting a previously unobtainable source of energy and of alleviating dependence on foreign oil. There are clear challenges which must be overcome, however, to fairly address public concerns over the amount of toxic chemicals used and the potential dangers posed to drinking water resources. Written from an engineering standpoint, this report aims to identify the challenges that the industry is facing while posing reasonable solutions. The body of the report examines established literature on the technology utilized by fracking, its impacts on the environment and human health, the current state of government regulations on fracking, its impact on the U.S. economy, and its required infrastructure, among other topics of interest.

With improving technology, many fracking problems are already being addressed. A challenge, however, is for industry to begin taking some appropriate, more preventative actions. Certain regulations have been enacted, yet opportunities still exist where industry can implement break-through concepts and abandon outdated and harmful technologies. Serious problems which must be addressed are the insufficient monitoring of the life of injected chemicals and the lack of options for handling produced wastewater. It would thus be of great value to equip public facilities with the ability to treat the complex waste water produced from hydrofracking, as many waste-water treatment plants in the country are not currently capable of this. Additionally, an overhaul of current regulations to increase their transparency and overall effectiveness would significantly minimize the hazardous footprint of the industry and improve its outlook for the future.
\end{abstract}

\section{INTRODUCTION}

Shale gas has received much attention over the past decade as a source of energy and raw materials for organic synthesis. Presently, it is a multi-billion-dollar economic sector that is growing rapidly. Many analysts suggest that its great availability in the United States poses a strong opportunity to decrease the cost of energy and commercial products, to provide jobs which build the infrastructure to support its processing and delivery, to create an additional export commodity to sell to foreign countries that need it, and to contribute significantly to the U.S. Gross Domestic Product (GDP). However, only $17 \%$ is available for extraction from the ground without a mechanism for enhanced recovery. The standard technique, through which an additional (36-46)\% may be obtained, is hydrofracking. Hydraulic fracturing - also called hydrofracturing, fracking, and HF for short - is the drilling and pumping of pressurized solutions into the ground to obtain natural gas from shale rocks, strongly related to the concept of gas permeability 
of the rock itself. Shale gas is an unconventional form of natural gas in the sense that it is trapped within the pores of shale rock instead of simply being contained in an underground cavity. Natural gas is composed of methane, carbon dioxide, nitrogen and hydrogen sulfide. This method is presently highly debated; some environmentalists claim that it is not possible to execute this process without significant and irreparable damage to surrounding ecology. On the other side of the issue, many for-profit corporations cite that it is not legal to prevent them from fracking and that the environmentalists' claims are unproven. More than that, these companies also indicate that it is not feasible on a fundamental level to stop hydrofracking since many Americans rely on it to provide energy for their day-to-day lives.

As the global energy needs increase greatly, it is very important to quantify the risks, potential losses, and prospective gains associated with the hydrofracking process. The strong public attention and impact from this issue, coupled with the wide variety of professionals required to work together and form a coherent opinion on the matter - corporate executives, lawyers, insurance companies, governmental regulating bodies, politicians, engineers, etc. - makes the evaluation process complex. Therefore, it is imperative to thoroughly expose the infrastructure that must be developed to sustain this process (section 1), a more detailed description of what hydrofracking is, the various chemical constituents it utilizes, and how it is executed, and its technological advances (section 2), environmental impacts and their mitigation (section 3), the relevant governmental regulatory agencies, as well as their evaluation criteria (section 4), and economics of hydrofracking and trends in demand, costs and market prices (section 5).

\section{TECHNOLOGY}

Hydraulic fracturing is not a new process - it has been around since the late 1940s. Vertical drilling for gas and oil has been around even longer than that. One major reason why we have seen a surge in shale gas harvesting within the last decade is due to the addition of horizontal drilling techniques (1998) and highly effective, though controversial, fracking fluids. The combination of these with the existing technologies has resulted in a cost-effective, feasible method for shale gas extraction. This section describes the key aspects of the overall shale gas extraction process while highlighting some areas which still have room for improvement.

\section{Geology}

Looking at a profile slice of the earth, the geology shows that the target formation, or the rock from which the natural gas is being extracted, is shale, usually located approximately 6,000 feet below the surface ${ }^{[1]}$. Compare this depth with another depth of concern, the aquifer, or water table where drinking water is extracted from, which is usually located approximately 50 to 200 feet below the surface. Between the aquifer and the shale are many layers of different interconnecting, impervious rock, as seen in Figure 1.

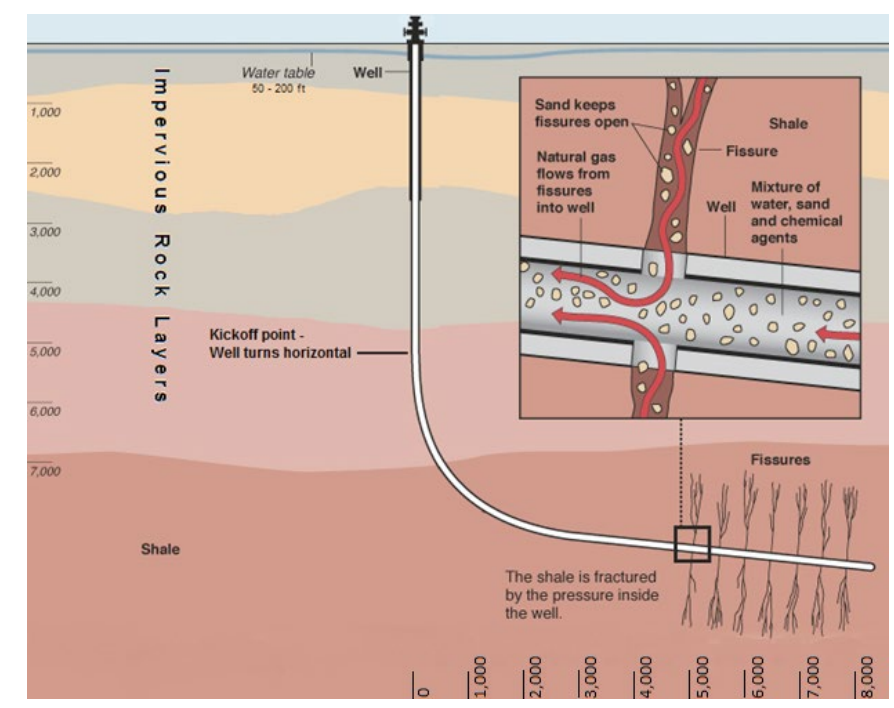

Figure 1. Schematic of geology showing shale, aquifer, and layers of impervious rock ${ }^{[1]}$.

Having an idea of the geological layers is important for a number of reasons. First, it shows that reaching the target formation (shale) requires drilling through the aquifer. This is important to keep in mind because any impact on the aquifer could have significant consequences. Second, it is interesting to note that the shale is located quite far below the aquifer and is separated from it by thousands of feet of impermeable rock.

\section{Drilling}

Vertical drilling: To access the target formation requires a multiple-stage, complex drilling process. After a suitable area has been cleared and a well pad has been built over the area to be drilled, all of the equipment is brought in. The process continues 
with the drilling of a vertical hole by a long drill bit with a sophisticated tip capable of chewing away at tough rock ${ }^{[2]}$. The drilling is done by traditional vertical methods, where the entire drill string is rotated from the surface. As the well is being drilled, it is lined with up to several layers of steel pipe (casing) and reinforced with concrete.

The reinforcement is held in place by concrete ${ }^{[3]}$. This prevents the well from collapsing upon itself and isolates the contents of the well from the surrounding rock, soil, and water systems ${ }^{[4]}$. A schematic showing the typical drilling procedure can be seen in Figure 2. Panel 1 of the figure shows the sharp tip attached to the bit, drilling the vertical hole. During the vertical drilling, the hole above and around the bit is filled and circulated with drilling mud-an aqueous slurry of additives used to help lubricate and cool the drill bit, making drilling faster and easier. The drilling mud also carries the cuttings, a fine rock particle mixture produced during the drilling process, out of the bore to be removed at the surface. After a significant portion has been drilled, the casing is lowered into place using a guide shoe. Note from panel 2 that the casing has been equipped with a centralizer, a flexible, springlike gasket to hold the casing in the center of the hole. This will ensure that the concrete completely and thoroughly surrounds the casing. Panel 3 shows the cement being fed down the casing.

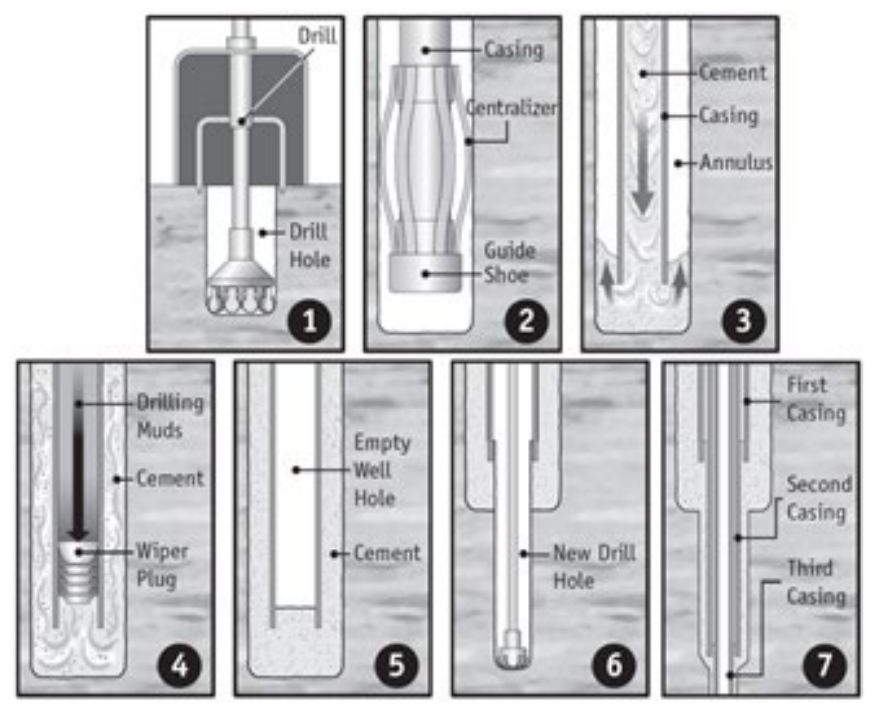

Figure 2. Process for vertical drilling [4].

High pressure at the feed-end, up to 9000 PSI ${ }^{[5]}$, helps to guide the cement all the way down the pipe and then out around and back up the hole, thus completely encapsulating the casing. After a sufficient amount of concrete is poured, a wiper plug is forced down the casing by drilling mud, as seen in panel 4 . This wiper plug clears out any concrete mixture from the inside of the casing before it hardens. After the concrete hardens, a smaller drill bit can be attached, and drilling continues; see panel 6 . This process is repeated until the proper depth is attained, usually having created several layers of concentric casing plus concrete along the way; as shown in panel 7.

While the schematics in panels 4-5 of Figure 2 seem to show a straightforward, simple way to encapsulate the steel casing, it is not always that easy. While encapsulating the casings that pass-through rock is fairly effective, the process for the sections that pass through the aquifer is more complex. Getting the concrete to stay localized to and cure directly around the casing is difficult and less effective. Furthermore, rock layers oftentimes exist that are closer in proximity to the aquifer and contain low levels of natural gas. This is not enough natural gas to harvest, but is enough to bubble up while the concrete is curing, reaching and dispersing into the aquifer; as seen in Figure $3^{[6]}$.

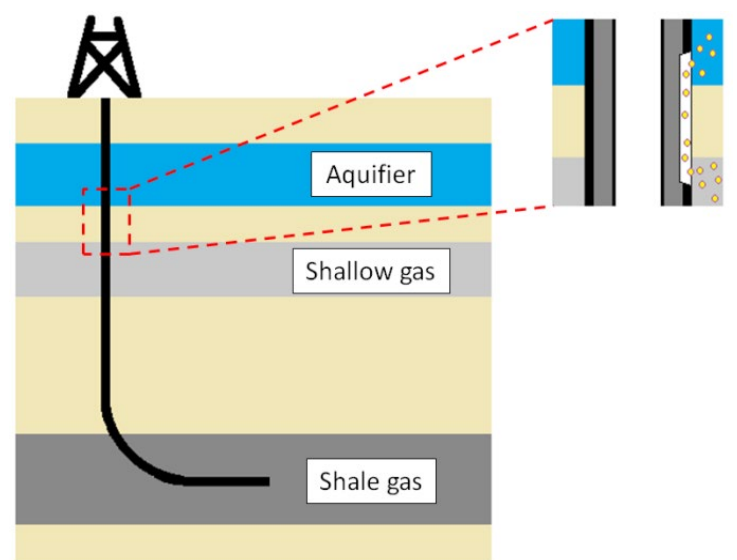

Figure 3. Schematic showing natural gas bubbling through wet concrete and into aquifer (inspired by Ref. ${ }^{\left[{ }^{[6]}\right.}$ ). 
The drilling and insufficient isolation of natural gas agrees with one common problem reported by residents local to fracking areas - that their drinking wells are often contaminated with natural gas and they can even ignite the gas as it desorbs from the water running out of their faucets ${ }^{[7]}$. It is the opinion of the authors of this paper that this can be considered evidence that the concrete encasement method needs improvements and should receive further research. Inadequate concrete encasement presents a challenge for future drillers and an opportunity to appease many upset residents by preventing natural gas pollution of their drinking wells. One potential solution would be to engineer a faster curing, in-situ concrete that stays in close proximity of the casing to seal more effectively.

Horizontal drilling: After drilling the vertical section to a specified depth, identified as the "kickoff point," the drilling team switches over to horizontal drilling. The motivation behind horizontal drilling lies with the fact that the shale is usually much more expansive in the horizontal direction, rather than the vertical; i.e. not very deep, but very broad. Therefore, by directional, or horizontal drilling, much more of the rock can be accessed to extract the natural gas. Figure 1 also illustrates the bend taken in the drilling path, starting from the kickoff point, and gradually making its way to completely horizontal. Though it is more expensive, the increased production usually outweighs the increased cost ${ }^{[8]}$.

The horizontal drilling is achieved by different means than the vertical drilling. After reaching the kickoff point, a different bit is attached, which contains a hydraulic motor at its tip. In this manner, the drill bit can be rotated without having to do so at the surface, making the process much more feasible from an engineering standpoint. The hole is guided via use of a "steerable motor," orienting the cutting over a gradual bend radius until the desired horizontal direction is achieved. The drilling can then continue in the horizontal direction for great lengths. As with the vertical section, these bores are subsequently lined with both steel casing and concrete ${ }^{[8]}$.

\section{Fracturing Process}

Once the horizontal section has been drilled and cased, the fracturing process can begin. Even though the horizontal drilling gives more access to the shale layer, the natural gas is still trapped fairly well between the layers of the shale itself. Accordingly, the layers of shale are fractured in a multi-stage process to aid in the gas recovery. The process begins by inserting a perforating gun at the end of the bit all the way to the end of the bore. Since the hole has been lined with steel casing and cement, it is essentially isolated from the shale and gas. The function of the perforating gun is to reconnect the hole with its surroundings. This is accomplished via the shaped charges of the perforating gun. The shaped charges are basically controlled explosives that are designed to direct the impact to a confined location, piercing through the steel, concrete, and out into the rock formation. As shown in Figure 4, panel A, the perforating gun creates fissures in the shale, at approximately 50 foot intervals ${ }^{[9]}$. The perforating gun is then moved along the length of the horizontal section until it has been adequately perforated. Next, the perforating gun is removed, and a water-based liquid is injected into the bore at very high pressures (up to $9000 \mathrm{PSI}$ ) ${ }^{[5]}$. This liquid, whose typical composition is described later, flows into the primary fractures that were made by the perforating gun and expands the fracture out along naturally weak regions in the shale, creating secondary fractures; (Figure 4), panel ${ }^{[9]}$.

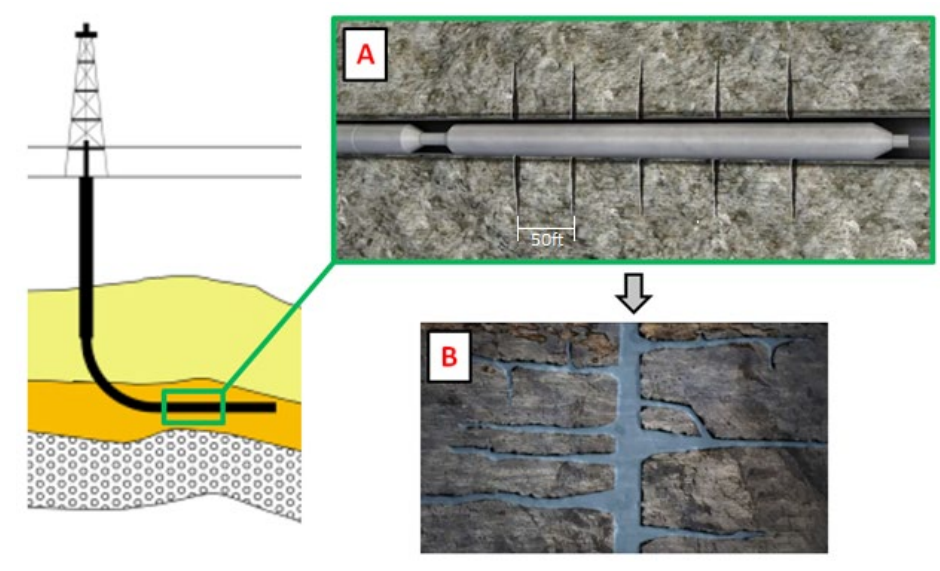

Figure 4. Schematic showing the use of the perforating gun to create punctures in the steel casing and cement so that the natural gas can feed into the pipeline ${ }^{[9]}$.

After the secondary fractures/fissures are made, another high pressure fluid is injected, this time containing a proppantsand grains or other materials that are used to hold open the fractures. This ensures that the gas contained in the shale will be able to continually flow through the fissures and into the well pipe even after the fluid is removed, as seen in the right hand side of Figure $1^{[9]}$.

\section{Chemicals}

There are several challenges that arise during the fracturing process, depending on the composition of the local soil and rock. 
The natural environment also poses some difficulties; bacteria, for example, can produce undesired gases and contaminate the product. Other organisms can reduce the efficiency of the fracturing process as well. Additionally, the high temperature and pressure inside the well bore make the process hard to control. The machinery involved in the fracturing process can also be damaged [9]. To control and increase the efficiency of the overall process, chemicals are introduced to the fracturing water with several purposes: to optimize the fracturing environment, to control the biological disturbances, and to protect the fracturing equipment. The chemicals can be generally classified into several categories: proppant, acid, breaker, biocide, pH adjusting agent, clay stabilizer, corrosion inhibitor, crosslinker, friction reducer, gelling agent, iron control, solvent, and surfactant.

Many of the fracturing fluid chemicals are known to be toxic to human body and wildlife, and several are known to cause cancer. The oil and gas industry and trade groups point out that in a normal fracturing process, the chemicals only make up about 0.5 $-2 \%$ of the fracturing water ${ }^{[10]}$. Considering the large amount of water used, the quantity of chemicals is significant. For example, in a four-million-gallon fracturing operation, 80 to 330 tons of chemicals are used. Therefore, knowing how all the chemicals function in the fracturing process and their hazards, as well as the possible environmental contamination in the water, air, and soil, is very important aspects of the fracking (Table 1).

Table 1. An example of the volumetric composition of hydraulic fracturing fluid ${ }^{[1,12]}$.

\begin{tabular}{|c|c|c|c|c|}
\hline $\begin{array}{l}\text { Component/Additive } \\
\text { Type }\end{array}$ & Example Compound(s) & Purpose & $\begin{array}{c}\text { Percent } \\
\text { Composition } \\
\text { (by Volume) }\end{array}$ & $\begin{array}{l}\text { Volume of } \\
\text { Chemical } \\
\text { (Gallons) }\end{array}$ \\
\hline Proppant & Silica, quartz sand & Keep fractures open to allow gas flow out & 9.51 & $2,85,300$ \\
\hline Biocide & Glutaraldehyde & Eliminate bacteria & 0.001 & 30 \\
\hline Water & & Deliver proppant & 90 & $27,00,000$ \\
\hline Surfactant & Isopropanol & Increase the viscosity of the fluid & 0.085 & 2,550 \\
\hline Gelling agent & $\begin{array}{l}\text { Guar gum, hydroxyethyl } \\
\text { cellulose }\end{array}$ & Thickens the fluid to suspend the proppant & 0.056 & 1,680 \\
\hline Breaker & Ammonium persulfate & Allow delayed breakdown of the gel & 0.01 & 300 \\
\hline Crosslinker & Borate salts & $\begin{array}{l}\text { Maintain fluid viscosity as temperature } \\
\text { increases }\end{array}$ & 0.007 & 210 \\
\hline Acid & Hydrochloric acid & $\begin{array}{l}\text { Dissolve minerals, initiate cracks in the } \\
\text { rock }\end{array}$ & 0.123 & 3,690 \\
\hline $\mathrm{pH}$ adjusting agent & $\begin{array}{l}\text { Sodium or potassium } \\
\text { carbonate }\end{array}$ & $\begin{array}{c}\text { Maintain the effectiveness of other } \\
\text { components }\end{array}$ & 0.011 & 330 \\
\hline Iron control & Citric acid & Prevent precipitation of metal oxides & 0.004 & 120 \\
\hline Corrosion inhibitor & $\mathrm{N}, \mathrm{n}$-dimethyl formamide & Prevent pipe corrosion & 0.002 & 60 \\
\hline Friction reducer & Polyacrylamide, mineral oil & $\begin{array}{l}\text { Minimize friction between fluid and the } \\
\text { pipe }\end{array}$ & 0.088 & 2,640 \\
\hline Potassium chloride & & Create a brine carrier fluid & 0.06 & 1,800 \\
\hline Scale inhibitor & Ethylene glycol & Prevent scale deposits in the pipe & 0.043 & 1,290 \\
\hline
\end{tabular}

Proppant: Proppant is used in hydraulic fracturing to keep the fissures open. This could allow gas or oil flow out and increase the production. On average, 300,000 pounds of proppant per well were used in the hydraulic fracturing process, and large sites can sometimes require up to more than 4 million pounds of proppant ${ }^{[10]}$. Sintered bauxite, zirconium oxide, ceramic beads can all be used as proppant, but the most commonly used proppant is sand. The required amount of sand for hydraulic fracturing is so great, that in the U.S., sand mining could be used as a metric for charting the extent of the hydraulic fracturing industry. However, sand mining can lead to high water consumption along with particulate and waste gas emissions. Accordingly, the environmental damage caused by sand mining has become an important issue ${ }^{[13]}$.

Biocide: Fracturing processes usually use surface water that generally contains a large number of bacteria such as sulfatereducing bacteria (SRB) and acid producing bacteria (APB) ${ }^{[14]}$. Bacteria grow underground in the well bore and create undesired hydrogen sulfide gas, which is corrosive and has the potential to damage fracturing facilities and decrease the product quality. The flow back water is oftentimes polluted by the bacteria. As such, biocide is added to control the growth of bacteria. A series of tests are used to determine the type and the amount of biocide to use in the fracturing process. Glutaraldehyde and 2-Bromo2-nitro-1,2-propanediol are two common biocides used.

Solvent, surfactant, friction reducer: Oil is a common fracturing product. However, oil does not dissolve in water nor acidbased fracturing fluids and, because of this, creates high surface tension that reduces fracturing fluid recovery. Solvents that dissolve in both fracturing fluid and oil are added to increase the contact between the two liquids and surfactant, which helps to reduce the surface tension. Friction reducers minimize the friction in undesired parts of the process, e.g. between the rotating 
bit and the fracturing fluid. These chemicals allow for higher efficiency and better overall production ${ }^{[15,16]}$. Methanol, isopropanol, polyacrylamide, petroleum distillate and various aromatic hydrocarbons are chemicals typically used for this purpose. A common additive is diesel. Diesel is very effective at solubilizing many of the nonpolar additives and created a more homogenous drilling fluid. Various components of diesel, however, such as benzene, toluene, ethylbenzene, and xylene are known to be carcinogenic and toxic to the liver, kidneys, and nervous system. Accordingly, the Environmental Protection Agency (EPA) has established regulation about using diesel in the fracturing under safe drinking water act ${ }^{[17-19]}$.

Gelling agent, breaker, crosslinker: The fracturing process requires high pressured fracturing fluid to bring proppant into the new fracture of shale and keep the fissures open to allow natural gas to flow out. This usually requires a large amount of surface water and high working pressure. Gelling agent and crosslinker are added into the fracturing fluid to increase the fluid viscosity. With higher viscosity, it is easier for fracturing fluid to bring proppant into the new fracture. This reduces the amount of surface water use and the working pressure. Breaker is then introduced into the shale to break down the gel structure of the crosslinked/ viscous fracturing fluid. The fracturing fluid is then removed, leaving the proppant in the fractures ${ }^{[15,20]}$. Peroxydisulfates are a commonly used breaker that break crosslinkers apart; guar gum, bisacrylamide, etc.

Acid, pH adjusting agent: Acid, usually hydrochloric, is used in fracturing fluids to dissolve rocks and remove drilling mud before the fracturing fluid injection. $\mathrm{pH}$ adjusting agent is used to maintain the $\mathrm{pH}$ value of fracturing fluid. This allows the other chemicals, such as crosslinker, to work under the desired pH environment so the characteristics will not be changed. Sodium or potassium carbonate and acetic acid are commonly used $\mathrm{pH}$ adjusting agent ${ }^{[21]}$.

Iron control, clay stabilizer, corrosion inhibitor: The underground formations differ greatly from well to well. The minerals, soil, and the chemicals used therefore pose challenges to successfully fracturing the shale. For example, the physical properties of clay can change because of and during the fracturing process and can plug the fractures. Chemicals such as carbonates and sulfates, notably calcium carbonate, calcium sulfate, and barium sulfate, could form and block the fracturing process, and rust could form on steel tubing and well casings. To deal with these challenges, chemicals such as Iron Control, clay stabilizer, and corrosion inhibitor are added into the fracturing fluid case by case to optimize the fracturing process. Salts, oxygen scavengers, ammonium chloride, ethylene glycol, and polyacrylate are used to achieve this requirement ${ }^{[16,22]}$.

Of all the chemicals used in fracturing process, diesel (as a toxic solvent), and sand (as the mostly used proppant), have the largest health and environment concerns due to their toxicity and high usages, respectively. Even sand mining alone causes great water consumption, waste gas emissions, and results in various health concerns related to crystalline silica. The toxic components of diesel such as benzene, toluene, ethylbenzene, and xylene could leak to drinking water systems through the fracturing process ${ }^{[19]}$. Regulations have been made by EPA and states to control these problems ${ }^{[17,18,23]}$. However, there are still difficulties and challenges. Report shows that some companies continue to use diesel or diesel derivatives that are often just as toxic ${ }^{[24]}$. The industry even argued that there are no regulations prohibiting the manner in which they are using diesel in their fracturing processes ${ }^{[25]}$.

Chemicals can greatly improve the efficacy of fracturing. Sometimes chemicals can even help to avoid secondary hazards such as bacteria in waste. However, such chemicals do pose a potential hazard to human health and the environment ${ }^{[15,26,27]}$. With the rising concern from the public, several methods and new materials have been developed to replace or reevaluate the old chemicals and reduce the hazard to human health and the environment. The technology of fracturing could also be improved over time to reduce the risk of leaks and air emissions. Regulations and resident awareness could be the most important forces that push the industry to develop better ways to do hydraulic fracturing.

\section{ENVIRONMENTAL IMPACTS}

The largest source of public mistrust for hydrofracking stems from its questionable effects on surrounding ecosystems and on human health. In brief, hydrofracking requires a substantial amount of water and a mixture of up to thousands of chemicals, many of which remain undisclosed, to be injected deep underground, where their physical and chemical impacts on groundwater are difficult to monitor. With the additional possibilities of air contamination, catastrophic spills, underground blowouts, and reports of home explosions and increased rates of cancer in areas exposed to hydrofracking, there is reasonable cause for public concern and interest, but also perhaps some healthy anxiety. To truly assess the environmental and health impacts of hydrofracking, it is necessary to examine each part of the process and determine where hazards to water, land, and air quality can occur, and by what means they can be detected.

\section{Water Usage}

To begin, it is important to understand how much water is consumed in the process, where the water is being taken from, and how it competes with personal usage. According to a study plan drafted by the EPA in 2011, the amount of water required to extract natural gas from a well varies according to the depth and porosity of the formation. Typically, this requirement is on the order of 2 to 4 million gallons of water necessary for each well ${ }^{[28]}$. Table 2, taken from the same EPA study plan, shows the average water needs for various shale plays. 
Table 2. Comparison of estimated water needs for hydraulic fracturing in different shale plays ${ }^{[11]}$.

\begin{tabular}{|c|c|c|c|c|c|}
\hline Shale Play & $\begin{array}{c}\text { Formation Depth } \\
\text { (ft) }\end{array}$ & Porosity (\%) & Organic Content (\%) & $\begin{array}{c}\text { Freshwater } \\
\text { Depth (ft) }\end{array}$ & $\begin{array}{c}\text { Fracturing Water } \\
\text { (gallons/well) }\end{array}$ \\
\hline Barnett & $6,500-8,500$ & $4-5$ & 4.5 & 1,200 & $2,300,000$ \\
\hline Fayetteville & $1,000-7,000$ & $2-8$ & $4-10$ & 500 & $2,900,000$ \\
\hline Haynesville & $10,500-13,500$ & $8-9$ & $0.5-4$ & 400 & $2,700,000$ \\
\hline Marcellus & $4,000-8,500$ & 10 & $3-12$ & 850 & $3,800,000$ \\
\hline
\end{tabular}

With approximately 35,000 wells fractured each year, this equates to a usage of 70 to 140 billion gallons of water annually.

According to Josh Brown of Chesapeake Energy, 3.6 trillion gallons of water are consumed annually in Pennsylvania, of which $0.19 \%$ is used for hydrofracking ${ }^{[29]}$. In the Barnett shale area in 2010 , out of the total 554 billion gallons of water used, 9.5 billion gallons, or $1.7 \%$, went toward gas production ${ }^{[30]}$. As a percentage of the total use, this is a small fraction of the water that is consumed yearly in areas where hydrofracking is prevalent. However, it should be understood that this usage comes in large bursts, as opposed to being spread out over the course of the year, as with regular human use. This may not allow the groundwater opportunity to maintain a steady level as it is used up, and the EPA has concerns that lowering the groundwater levels alone can lead to chemical contamination of the water by naturally occurring minerals and can also lead to bacterial growth, resulting in odor and flavor problems. Lowering surface water levels can result in changing a stream's velocity, temperature, and depth, and because surface streams and aquifers have a synergistic relationship, altering one significantly will affect the other. The effects of large volume water withdrawals would be most severe in arid climates, such as that of North Dakota.

\section{Chemical Mixture and its Flow History}

On top of complications from water consumption, concern stems from the nature of the chemicals used in the hydrofracking fluid. As previously discussed, the hydrofracking fluid consists largely of water and proppant, which is usually sand, and thousands of chemical additives in small concentrations. The amount of chemicals used depends upon conditions specific to the well that is being fractured and may be determined by means of computer modeling ${ }^{[31]}$. Table $\mathbf{1}$ above, taken from the EPA's aforementioned study plan, shows a small assortment of the chemicals used in the fluid. The exact number and identity of chemicals used remains undisclosed, although the EPA has been able to compile a considerable list of known chemicals and an estimate of some of their concentrations. The list contains about 1,000 entries, but it still remains unknown how this number compares with the actual number of chemical additives.

The chemicals used fall into a range of toxicities, from being relatively benign, like guar gum and polyacrylamide, to poisonous, like ethylene glycol and glutaraldehyde. The number of chemicals and their identities are considered proprietary by oil and gas companies and are thus well protected. Without knowing the exact identity and concentration of the chemicals, it is difficult to assess the health risks posed by the fracking fluid alone. An investigation by the US House of Representatives Committee on Energy and Commerce, however, was able to yield the following: “....between 2005 and 2009, the 14 [leading] oil and gas service companies used more than 2,500 hydraulic fracturing products containing 750 chemicals and other components," including, “...29 chemicals that are: (1) known or possible human carcinogens; (2) regulated under the Safe Drinking Water Act for their

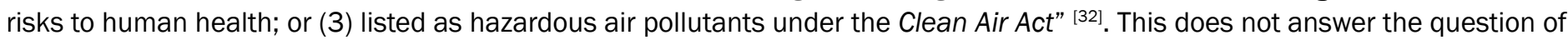
whether these 29 chemicals are in harmful concentrations or not. It does bring up another contentious issue, however, which is the exemption of hydrofracking activities from the Safe Drinking Water Act and Clean Air Act.

In an ideal situation, the hydrofracking fluid would not be at risk of entering drinking water resources in the first place because of the protections put into place, such as cementing around the wellbore, geologic testing of the subterranean layout in each play, and constant monitoring of the fracking conditions. Concern, rather, comes from the real possibility of negligence, poor well construction, oversight, and human error leading to an uncontrollable release of harmful chemicals into drinking water resources. There are several modes by which this could occur. The chemicals could migrate from the shale formation to aquifers by means of large fractures, poorly constructed wells could lead to blowouts under high pressure, and poor treatment of wastewater and chemicals during transportation could lead to accidental surface spills.

\section{Blowouts and Groundwater Contamination}

Incidents of underground blowouts as a result of shale gas drilling have been reported, although rarely. The Texas Railroad Commission has reported twelve blowouts in the Barnett shale play, two of which were underground ${ }^{[33]}$. The causes and consequences of these blowouts are not publicly available. Statistics on the frequency of blowouts for offshore oil and gas wells is compiled by the International Oil and Gas Producers Association, although there is little data on the frequency of onshore gas and oil well blowouts ${ }^{[34]}$. There are a few analyses, however, which outline the subsequent damages caused by underground blowouts. For example, Kelly and Mattisoff reported on a blowout in Ohio in 1982 caused by the unexpected drilling of a high-pressure gas pocket ${ }^{[35]}$. The gas immediately shot up the uncased wellbore and was transported through natural fractures in the ground. Fifty one families in an $11 \mathrm{~km}^{2}$ area ended up being evacuated, and eight months after the leak was contained, harmful levels of gas concentrations were still found in four water wells ${ }^{[35]}$. 


\section{Wastewater}

After the fracturing period, the pressure on the well is released, and a fraction of the fluid migrates back to the surface as "flowback," a process which can occur over the course of several weeks ${ }^{[36]}$. The amount of fluid recovered is estimated at about 25 to $75 \%$ in some areas, such as the Barnett shale play, ${ }^{[37-39]}$ and 10 to $30 \%$ in others, such as the Marcellus shale play ${ }^{[40]}$. The volume of flowback is not reported to any state agencies, however, meaning these estimates could be very inaccurate. Regardless, the remainder of the injected fracking fluid is known as "produced water," which flows out of the well concurrently with the harvested hydrocarbon gases. Flowback and produced water together make up the wastewater from hydrofracking. The wastewater is handled in a number of different ways, including treatment followed by reuse for hydrofracking in the same well or a different well, injection into Class II underground injection control (UIC) wells, or treatment at publicly owned treatment works (POTW) or commercial wastewater treatment (CWT) facilities.

Recycling hydrofracking fluids is a beneficial practice, as it reduces strain caused by ground and surface water extraction, and it postpones the need to treat the water. Before being reused, the fluid does need to be treated to some extent in order to account for the dissolution of naturally occurring minerals from the shale formation and for biogeochemical interactions that take place during injection. To facilitate this procedure, researchers at Texas A\&M are currently pilot testing a mobile treatment system in the Barnett shale region ${ }^{[37]}$. If the recycled fluid is to be used in a well that has already been injected, however, there is concern over the structural integrity of the well after one or more injections, which is not well understood. Recycling, though beneficial, is not a final solution, as the hydrofracking fluid will still eventually come to the end of its cycle and need to be treated before being returned to its source or used for a different purpose. If it does not get treated, then at the least it will need to be sequestered in a UIC.

Injection into UICs is currently the most common method of treating hydrofracking wastewater. Wherever this is not an option, the wastewater can be sent to a POTW or CWT for treatment before being returned to drinking water resources. While a CWT may be specially equipped to handle known contaminants in the wastewater, this is not the case with POTWs. The sodium chloride content, for instance, damages equipment ${ }^{[38,41]}$, bromides lead to toxic brominated disinfection byproducts, and POTWs lack treatment methods for radionuclides. For these reasons, the state of Pennsylvania has limited the disposal of hydrofracking wastewater at POTWs to less than $1 \%$ of the POTW's average daily flow ${ }^{[42]}$. Additionally, hydrofracking wastewater is no longer allowed to be sent to 15 different POTWs in Pennsylvania ${ }^{[43]}$. Improving POTWs so that they could handle the known and unknown contaminants in hydrofracking wastewater would help by allowing the oil and gas companies more options for how they manage the wastewater. This would first require a disclosure of the fracking fluid's chemical composition.

Having knowledge of these dangers, experimentation is needed to determine where such phenomena as leaching of chemicals into drinking water are occurring or can be projected to occur. Typically, if contamination is found in water sources, it is difficult to attribute its origin solely to the practice of hydrofracking, as opposed to natural causes. Additionally, it is difficult to determine if water quality in specific areas has been contaminated only in recent times, or if it has historically been contaminated. In this same vein, it remains to be seen what projections for water quality in the future hold should hydrofracking become even more common. Answering these questions requires case studies of a range of wells in different shale plays over a substantial period. The EPA, for instance, has planned such an investigation on direction from Congress with preliminary reports to be released by late 2012.

\section{Landscape Effects}

After consideration of the source credibility (and of the later sections on economy and regulating bodies), it is important to highlight some of the plausible, potential, and commonly reported negative impacts of the hydrofracking technique. These are the greenhouse gases which are emitted by fracking fluid transport vehicles and drills, soil erosion surrounding drainage basins due to stirring up of previously undisturbed soil by commercial vehicles, and the classification of the types of contact that humans have with hydrofracking chemicals in their surroundings and their unintended impacts. The effects on the immediate area surrounding drill sites are much less severe than previously. Hydrofracking with horizontal drilling can explore more underground resources with less surface area than ever before. It is through cautious consideration that we can identify the most dangerous aspects of this emergent technology.

If these challenges can be overcome, hydrofracking is sure to be a part of the American energy landscape for some time to come. But then again, many governmental regulating bodies have given the technology a 'pass' and allow it to continue even with these issues. It is the job of engineers to criticize and then create changes in the technology. It is due to our unique understanding of matters of scale and fundamental sciences that we can weigh the relevant impacts as engineers. Once we understand the negative impacts, we can begin to spend time and effort minimizing them, of which some suggestions are offered.

One trend in the fracking process is decreasing surface landscape impact. The fracking process requires less surface area than ever ${ }^{[44]}$. In the 1970s, 20 surface acres allowed for the exploration of approximately 500 subterranean acres. Presently, due to horizontal drilling, 6 surface acres allow for the exploration and acquisition of gases in approximately 3,200 subterranean acres.

Flammable water near fracking sites is due to methane contamination. This methane must be recovered, as it can become 
desolvated when entering kitchens and bathroom areas in homes. The dilution of methane into enclosed atmospheric spaces has been known to sustain combustibility, which can be set off by a spark from the faucet or any metal on metal contact ${ }^{[7]}$. Therefore, methane in potable water sources represents an extreme hazard. Knowing that some of the environmental impacts of fracking can be caused independent of hydrofracking complicates matters. Methane-water concentrations should be monitored regardless of the extent to which it is sourced from hydrofracking incidents. One study found that seven percent of wells in New York State possess the critical concentration or higher to be inflammable ${ }^{[45]}$. Methane recovered from drinking water can be put into plants and burned with the rest of natural gas to produce energy.

It might be advantageous to decrease the number of companies that monitor and formulate the hydrofracking fluid to increase uniformity with respect to process conditions and the implementation of new regulations. Furthermore, this simplifies the adjustment phase companies face during changes in regulation and representation in discussions regarding fracking policies. It is nearly impossible to enforce all of the new decisions being made in courts and other levels of government with the large number of companies to delegate to presently, of which there are over 1000.

For those municipalities where the drinking water is contaminated, purification systems that neutralize the effluent toxicity of these compounds that have not been a problem previously should be developed and incorporated into existing water treatment plants. These should be in the wastewater treatment processes where toxicity may not be present now but is highly probable. This is a preventative measure for the case wherein water tables somehow pick up portions of these compounds. Presently, in many municipalities surrounding fracking, including larger cities such as New York, Cleveland, and others, there are no measures in place to filter xylenes, benzenes or other aromatic compounds.

Even if water purification were no longer an issue, there will be other effects from the presence of these aromatic compounds. These benzene derivatives are called aromatics because they typically have strong odors, an indication that they have a reasonable vapor pressure at STP. The long term effects of inhalational exposure and other effects are outlined in their MSDS sheets and are likely to be non-negligible. Critical studies of the present impact can and should be performed. A good resource of incidents related to fracking on a location-specific basis are reported at fracktrack.com ${ }^{[46]}$.

All hydrofracking compounds, without exemption, should be public knowledge such that their structure and health effects can be evaluated. If these mixtures are intellectual property or proprietary, then NDA agreements must be signed by respectable third-party evaluators and must participate in a peer-review-like process. Again, if the number of companies who are allowed licenses to frack is limited, then the propriety issue evaporates.

Furthermore, many estimations neglect that in many instances, supply water and disposal water should not be taken from, and then disposed to the same place. When water is sourced from a body and then put back into that body, it results in a "double dilution." The double dilution process puts more chemical in a smaller volume, and its concentration increases over time. This is different from the preferred method of taking water from a source, utilizing it in fracking, and then treating the water before providing it back to the source or recycling in the fracking process.

Marcellus shale drilling plays in the western and upstate New York region are surrounded by the Susquehanna River. This water is sourced in the Osteogo Lake of Cooperstown, NY and from the West Branch of the Susquehanna. It has an outlet in the Chesapeake Bay of Haavre de Grace, Maryland and therefore interconnects with the Atlantic Ocean. This river has a volumetric flow rate of $40,080 \mathrm{ft}^{3} / \mathrm{s}$ and represents half of the inflow into the Chesapeake Bay. The river also interconnects with the Delaware Basin which flows throughout New Jersey. A significant portion of predicted Marcellus Shale sources of natural gas underlies New York City's water reservoirs and aqueducts. By nature of the hydrofracking process, interconnects and break boundaries between subterranean cavities are created. These particular reservoirs are the source of $90 \%$ of NYC water. It therefore is of great concern that this process is occurring in the region.

Pollution of the Susquehanna system would be an unwieldy cleanup operation, comparable to the PCB contamination of the Hudson River by GE in the 40 s to the $70 \mathrm{~s}^{[47]}$. If it were deemed necessary for cleanups in a region affected negatively by fracking, the companies doing the fracking should be fiscally responsible.

One method to determine if fracking is the source of contamination and toxicity is the use of isotopic fingerprinting tracer compounds. Since $25 \%$ of the injected mixture is recovered within several weeks of injection, this method is a quick and relatively cheap way to determine if the toxicity is due to hydrofracking.

There is the possibility of earthquakes and enhanced seismic activity around fracking sites due to the breaking down of underground structures and removal of fluids. Perhaps these regions would make good sites for composting and landfills. Government surveyors frequently search for new sites for trash and refuse abatement and fracking sites may make it possible to achieve both.

\section{Health Impacts}

Based upon the broad information available, it appears the following set of topics warrant a modification of present methods and offer potential for immediate positive outcomes. One thought would be moving people that have tested positive for toxicity to 
carcinogenic and mutagenic compounds such as xylenes to safer areas. Based upon the surrounding ground water sources, the contamination is from fracking fluid entering the aquifers. This is especially important since exposure to these compounds has been shown to increase the rate of rare forms of cancer, cause stillbirths, cause hypertension, and can lead to the death of small animals ${ }^{[48]}$. Xylenes, a class of dimethyl substituted benzenes, and pyrans are not present in drinking water naturally as their chemical cousin, benzene, is known to be present in very small, specific concentrations. When xylenes are present in blood, urine, and drinking waters that are above MSDS and safe medical exposure limits, there should be a relocation process that occurs for those individuals. Some critics of the idea to relocate those contaminated with xylenes may say that it is not the government's right to move them or rather that it is their right to stay where they are. However, indirect contact is an unreasonable risk to these people, and the overall economic impact of trucking in water to cisterns, as is a current protocol, is unsustainable.

Furthermore, the increased levels of barium, strontium, and bromides have altered the overall salinity of the Ohio River, whose confluence surpasses even the width of the Mississippi. This can cause health impacts such as hypertension to those drinking such waters. Cattle are dying from eating the grass ${ }^{[49]}$.

\section{Regulations}

Due to the potential environmental impacts associated with extracting hydrocarbons from the ground, the U.S. EPA has long regulated the oil and gas industry under a variety of statutes to ensure that the land, water, and air remain protected ${ }^{[50]}$. Many of these statutes apply directly to shale gas hydraulic fracturing, though some have been modified to include exemptions for shale gas. Many of these exemptions have become quite controversial and are contested to have led to substantial environmental pollution. The possibility of these statutes being rewritten in the future, becoming much stricter, could necessitate the re-engineering of many of the traditional fracking processes; presenting difficult challenges and opportunities.

Several key acts which govern the land and water are the Resource Conservation and Recovery Act (RCRA), the Safe Drinking Water Act (SDWA), and the Clean Water Act (CWA). RCRA governs the generation, transportation, treatment, storage, and disposal of hazardous waste-applying also to the impoundments used to store used fracking fluids. The SDWA pertains to activities that could contaminate groundwater sources of drinking water due to migration of injected fluids from subsurface activities, while the CWA governs discharges to surface waters. The SDWA is regulated in part by the Underground Injection Control (UIC) program [51,52]. The EPA has adopted technology-based requirements known as Best Practicable Control Technology Currently Available $(B P T)$ and has added measures to prohibit pollutants being dumped into navigable waterways ${ }^{[53]}$.

While these acts outline a very sophisticated system of regulations and preventative measures for protecting the environment, most of them have been modified to include exemptions that pertain specifically to shale gas fracking. For example, exploration and production (E\&P) wastes of the shale gas process are exempt from RCRA guidelines ${ }^{[54]}$. Additionally, current legislation excludes natural gas activities from UIC jurisdiction, unless diesel fuel is specifically one of the components ${ }^{[17]}$. Finally, many pieces of the legislation have even redefined "pollutant," to specifically exclude fluids injected into the ground during the shale gas fracking process. Several accidents and examples of pollution stemming from some aspects of these exemptions have been found ${ }^{[35]}$. These have resulted in public outcry and condemnation of the fracking process as a whole, claiming that the motivation for these exemptions was originally tied to politics and big business, making their future unclear.

Other important acts relevant to the shale gas industry provide guidelines for protecting the air; one such act is the Clean Air Act (CAA). The CAA governs the emissions of hazardous air pollutants and greenhouse gases. Preconstruction and operating permits are required, obeying New Source Performance Standards (NSPS) and National Emission Standards for Hazardous Air Pollutants (NESHAPS), documenting and restricting emissions of "hazardous air pollutants" and "criteria air pollutants." Mandatory Greenhouse Gas Reporting Rule requires documentation of greenhouse gas emissions ${ }^{[55]}$. Furthermore, major producers/ emitters are subject to review under Prevention of Significant Deterioration (PSD) and Best Available Control Technologies (BACT) programs ${ }^{[56]}$. Again, these regulations aim to ensure that the air is protected, though the occurrences and extent for air pollution from shale gas fracking are usually regarded as fairly minor when compared to the potential hazards posed to the land and water.

While most of these acts provide great framework for protecting the air, land, and water, it is likely that many of them will be reviewed in the future to ensure that their exemptions pertaining directly to shale gas extraction do not compromise the efficacy of the programs as a whole. Furthermore, extensive tests and studies will likely need to be done to evaluate the extent of existing and potential future damage from the process. Accordingly, this presents a challenge and an opportunity to begin exploring alternative practices, methods, and procedures to ensure the land, water, and air remain clean and protected ${ }^{[57-60]}$.

In Table 3, FTE stands for "full-time equivalent." The Low and Average designations describe low and average development scenarios likely to take place in the near future in the state, so they can be taken as "at least" and "expected" values, respectively. The NYS DEC report also suggests a conservatively-estimated \$31 million to \$125 million in income tax revenue for the state from the development of fracking ${ }^{[61]}$. 
Table 3. Maximum Direct and Indirect Employment Impacts on New York ${ }^{[61]}$.

\begin{tabular}{|c|c|c|}
\hline & \multicolumn{2}{|c|}{ Total Employment (FTE jobs) } \\
\hline Scenario & Low & Average \\
\hline Direct Employment Impacts & 6,198 & 24,795 \\
\hline -Construction Employment & 4,408 & 17,634 \\
\hline -Production Employment & 1,790 & 7,161 \\
\hline Indirect Employment & 7,293 & 29,174 \\
\hline Total Employment Impacts & 13,491 & 53,969 \\
\hline Total Employment as a Percent of New York State 2010 Labor Force & $0.20 \%$ & $0.70 \%$ \\
\hline
\end{tabular}

\section{Projections for 2035}

The comparison of 2010 data to 2035 projections from the EIA are shown succinctly by the INGAA in Table 4 [62].

Table 4. 2010 Data vs. 2035 Predictions ${ }^{[57,58]}$.

\begin{tabular}{|c|c|c|}
\hline Shale gas as... & $\mathbf{2 0 1 0}$ & $\mathbf{2 0 3 5}$ \\
\hline \% of U.S. natural gas production & $23 \%$ & $49 \%$ \\
\hline$\%$ of U.S. natural gas consumption & $21 \%$ & $51 \%$ \\
\hline \% of U.S. annual energy use & $5 \%$ & $13 \%$ \\
\hline
\end{tabular}

It is readily observed that shale gas will more than double in collection and use over this 25-year span, reaching around half of all natural gas produced and consumed and $13 \%$ of total energy use in the U.S.

The graph shown in Figure 5 shows that by 2035, the U.S. will draw very near to switching from a net importer of natural gas to a net exporter ${ }^{[63]}$. The exact implications for the community impact of fracking are difficult to determine, as well as the costs of construction and production, although costs of a new technology can generally be expected to decrease as processes become better understood and optimized over time. What is clear from these projections, however, is that natural gas produced from fracking is only expected to become a larger player in the U.S. energy market and overall economy in the near future. Any changes to the fracking process, particularly those that stem from concerns about the bulk amount of material, should be addressed as quickly as possible, as it is clear from the ElA projections that the applications of this technology will continue to rapidly expand each year, as seen in Figure 5.

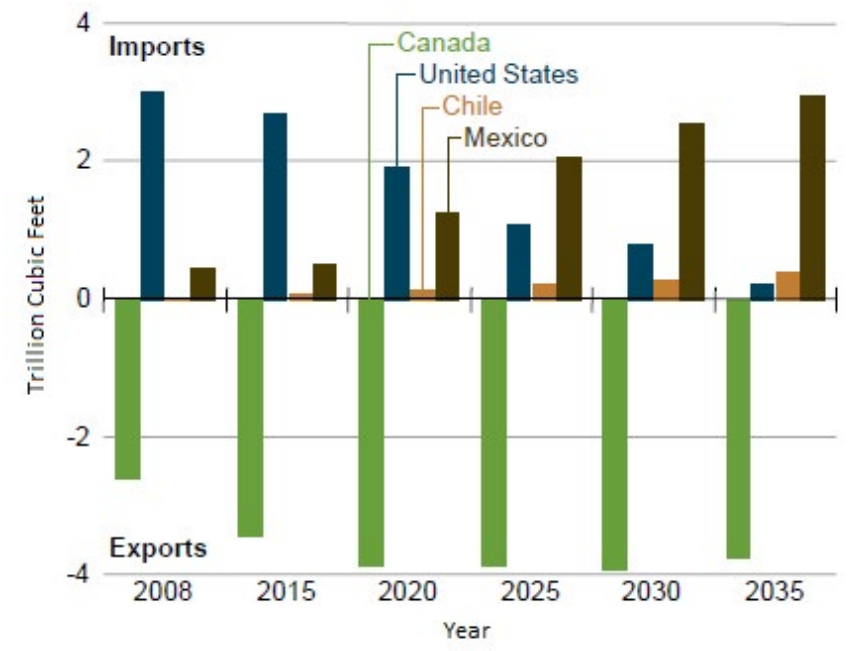

Figure 5. America's natural gas imports and exports, data and projections ${ }^{[63]}$.

\section{INFRASTRUCTURE}

The success of hydraulic fracturing has brought about huge economic benefits by unlocking previously inaccessible natural gas reserves, but meanwhile it poses a serious challenge to the building, expanding, and upgrading of infrastructure that arises from the fast production of natural gas. For instance, the abundant crude from Alberta oil sands has spurred the need to construct the massive "Keystone XL" pipeline to carry the crude to the Gulf of Mexico. Though it was temporarily delayed, one can tell that a well-developed infrastructure network is a prerequisite for implementing a fracking project in the field.

The infrastructure network is related to producing the shale gas, gathering the natural gas, midstream processing of shale gas, and transporting the gas to the market. In the case of the U.S., over the next 25 years, the Interstate Natural Gas of America 
(INGAA) suggests a significant infrastructure network development to accommodate the production of natural gas. Specifically, the U.S. will need to add over 43 billion cubic feet per day of incremental mainline capacity; 1,400 miles per year of new gas transmission mainline; 16,500 miles per year of new gathering line, 600 miles per year of new lateral pipeline to/from natural gas-fired power plants, processing facilities, and storage fields ${ }^{[64]}$. However, these are just a portion of infrastructure needs. Additional infrastructures, such as local transportation, processing plants, and liquefied natural gas terminals, are all required for the whole infrastructure network. Discussed below are the key infrastructure needs and recent development linked with the burgeoning of shale gas production by the hydraulic fracturing technique.

\section{Fracking and Production}

A commonly used drilling approach in fracking is horizontal drilling, which involves drilling wells deep enough to the rock layer containing the substance to be extracted. This drilling activity significantly increases the local demand for raw materials, i.e. concrete, steel, and site services, which means abundant manpower. Also, it involves the procurement of necessary equipment, such as slurry blenders and many high-pressure and high-volume pumps ${ }^{[65]}$. All the above demands put a burden on the local facilities that produce, transport, and distribute these goods and services.

Perhaps a more noticeable effect of the fracking process on local facilities is due to the large amount of chemicals used. In the process, large quantities of water, sand, proppants, and chemical additives are injected into the rock layer. These materials often need to be transported to distant areas where the fracking site is located. This generates pressure on regional transportation, especially places with less-developed transportation networks. Roads and highways, in most cases, need upgrading, which is neither a responsibility of the gas industry or private companies. Therefore, the fracking process could potentially disturb the local transportation.

Rail systems, though capable of carrying more goods - one rail car carries about four truckloads of product - , are also stressed because of the large amount of raw material and equipment used in a fracking site. However, it helps eliminate some of the truck traffic that has congested small communities in the fracking area. For example, the Eagle Ford Shale has prompted the expanding of Hondo Railway from 13,000 to 80,000 feet of track, which is capable of moving 15,000 rail cars carrying fracturing sand, crude oil, ethanol, and power plant parts. This, perhaps obviously, chould ease the local transportation burden.

Another concern is the disposal and recovery of waste when the liquids are pulled back from the wells. Since more than 700 chemicals, many of them known carcinogens, are present in the waste, proper treatment of these substances becomes a question. In addition, the incomplete disclosure of fracking chemicals adds to the difficulty of safely treating the wastewater. Many wastewater plants are not equipped with the technology that could handle the complex toxins in wastewater, and therefore cannot eliminate all the waste before discharging. To minimize the negative effect of fracking wastewater, a cooporative effort between the gas industry, government, and waste treatment facilities is needed urgently.

\section{Gathering and Processing}

After natural gas is extracted to the surface, it must be carried to processing plants by gathering, transmission - interstate and intrastate, and distribution pipelines. Figure 6 summarizes the whole transmission process of natural gas and oil from producer to customer.

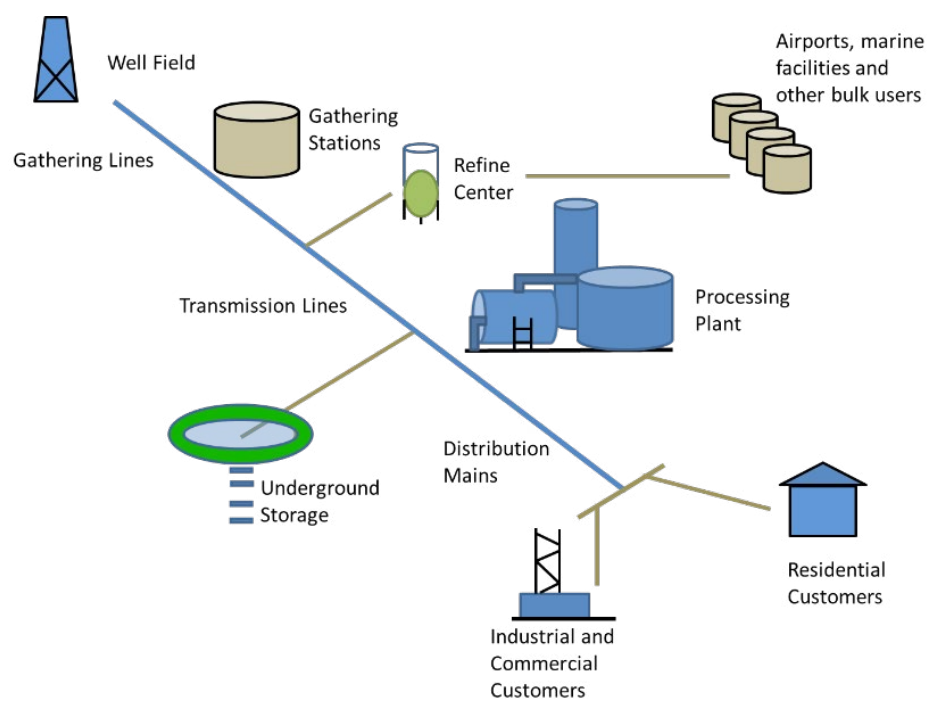

Figure 6. Transmission of natural gas and oil from producer to customer ${ }^{[66]}$.

After the natural gas is extracted from underground, it needs to undergo several processing steps before entering the gather- 
ing line (Figure 7). Since the extracted natural gas contains hydrocarbon liquids and water which could interfere with the natural gas compressors and other equipment, these contents need to be removed first. This is typically done at or near the wellhead where the dehydration and processing plants are. To prevent the remaining liquids from condensing during operation, different equipment is installed along the pipeline, which also monitors small amounts of lubricating oil that leaks into the natural gas stream ${ }^{67]}$. Then, the gathering pipelines carry the remaining natural gas to other plants, such as amine units, for removal of hydrogen sulfate or carbon dioxide, and dehydration and mercury removal plants for further purification. Finally, the gas is sent to a demethanizer to separate natural gas liquids (NGL) from natural gas that meets pipeline specifications to be transported via transmission pipelines ${ }^{[68]}$.

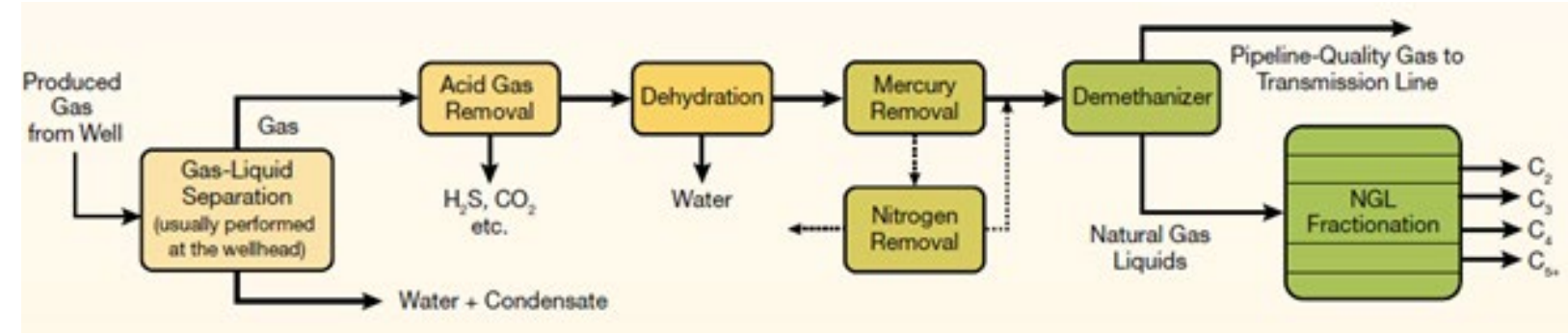

Figure 7. Processing step of raw natural gas ${ }^{[69]}$.

Since these pipelines usually extend long distances, the investment can be substantial. According to the Energy Department, about 1,000 Marcellus shale wells sit uncompleted, mainly because of a lack of pipeline infrastructure. Recently, Williams, an energy infrastructure company, signed a new contract that allows it to extract, transport, and market NGL and olefins from the offgas near Fort McMurray, Alberta. A total capital expenditure will be between $\mathrm{CA} \$ 500$ million and CA $\$ 600$ million. Caballo Energy, LLC is now constructing a cryogenic processing plant to serve the booming natural gas output in the Mississippi Lime and Cana Woodford Shale plays. The facility will be able to process 60 million cubic feet of natural gas per day, improving Caballo's processing capacity to approximately 100 million cubic feet of natural gas per day.

\section{Transporting the Natural Gas to Market}

The modern day natural gas transportation system consists of a complex network of interstate and intrastate pipelines connecting the producer and end-use market. Aside from gathering pipelines, transmission pipelines are responsible for moving the natural gas from processing plants/from import terminals to high-demand centers, where they tie into distribution networks. The distribution pipelines serve as back roads and neighborhood lanes, carrying the gas with small diameter lines from the transmission system to end users ${ }^{[70]}$. To adjust to the demand change caused by the drop of natural gas prices, the transmission and distribution network will need expanding and upgrades. Figure $\mathbf{8}$ is a typical example of the adjustment and augmentation of infrastructure to support an active Marcellus Shale play.

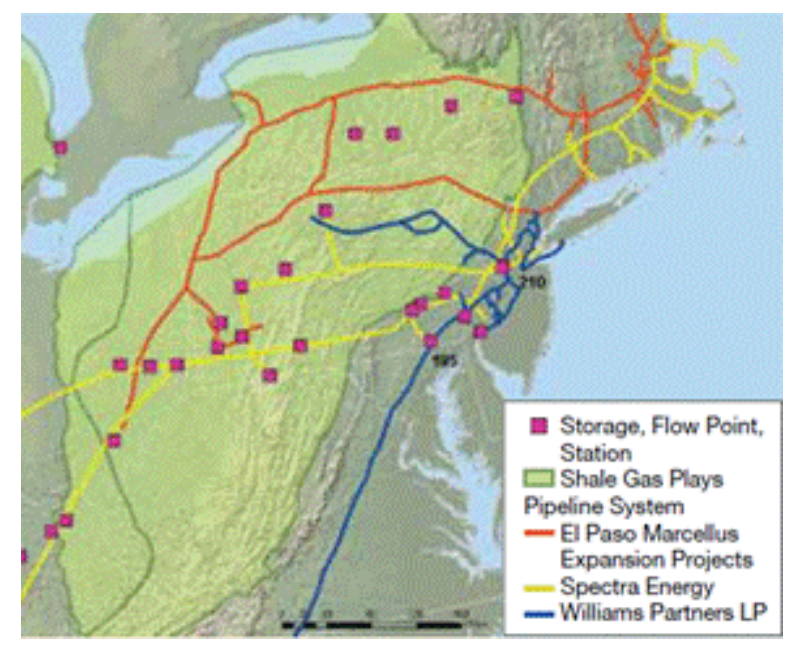

Figure 8. Extensive natural gas pipeline has been built to enable the development of the Marcellus Shale Play [69].

Many shale gas projects in the northeastern U.S. are aimed at strengthening the demand and supply chains between Marcellus Shale producers and northeastern markets. The Northeastern Supply Link and the Atlantic Access Pipeline project will enable the supply of Marcellus Shale to the market. The first project was designed to be able to deliver approximately 250 thousand dekatherms per day (MDth/day) of natural gas from the Leidy hub in Pennsylvania to pipelines in New Jersey. Thirteen miles of additional pipe segments will have been required to be constructed besides additional compression and existing facility modifications. 
Energy companies have been increasing the capacity of midstream assets in active shale plays. Spectra Energy Corp., Enbridge together with DTE Energy Corp. are to develop a Nexus Gas Transmission project to move natural gas from the Ohio Utica shale to markets in the Midwest and Canada. The estimated cost of new pipelines through northeastern Ohio and parts of Michigan would be $\$ 1.2$ billion to $\$ 1.5$ billion. The Utica Shale, a relatively new shale, has some of its part lying beneath the welldeveloped Marcellus shale, which already has hundreds of oil and gas wells.

The construction of transmission and distribution pipelines requires complex negotiation involving environmental, economic, and safety concerns. For instance, the construction of an interstate natural gas pipeline to New York City from the Marcellus Shale has attracted a series of protests due to the safety concerns of the pipelines being too close to schools, parks, and hospitals.

If the U.S. is to sell the natural gas to foreign markets, seaport, basic infrastructures already in place should be capable of handling the burden. However, massive port facilities need to be built by exporters to liquefy the gas to about $-260^{\circ} \mathrm{C}$. This can significantly drive up the cost. Then, a fleet of specialized tankers are used to transport the gas by sea. The U.S. energy companies and industry would like to sell gas overseas, from which they can sell at much higher prices and make higher profits. Meanwhile, U.S. utilities, manufacturers, and residential customers want to keep the gas price low. As a result, this again involves a conflict of interest considering whether U.S. should ship the surplus natural gas to oversee markets.

The potential large demand increase and shale gas production has motivated the massive development of infrastructure. However, the success relies on the contingent supply of dollars and the willingness to take risks. To lower the risks, one needs to weigh the balance between the capital output of infrastructure and potential reward of a shale gas project. In addition, certain laws or regulations should be established to specify gas companies' responsibility for developing public infrastructure so that it is not stressed because of intensive fracking activity.

\section{POINTS OF CONTROVERSY}

Public awareness is one important aspect of the hydraulic fracturing process. Several non-governmental organizations monitor the industry and disclose the facts to the public. However, the responsibility should not be placed on only non-governmental organizations, but also the government. Every resident should be interested in the energy independence of the US and in helping to monitor the industry as well as push it to improve. The success of the fracking industry is not only enjoyed by gas companies, but it instead relates to and benefits the economics of the country and the lives of its citizens as well. It is everyone's responsibility to push and support the industry to improve. There have been many issues in the recent past over the debate of hydrofracking best practices and whether it is safe to continue fracking. Many hydrofracking critics cite that fracking is bad for the environment and its side effects pose a significant public health threat. Governors, regulating bodies, engineers, public figures, and Grassroots movements have all weighed in. Charles Groat, a well-respected geologist published his analysis in Nature ${ }^{[71]}$, and in doing so claimed that he was an independent, un-biased source of fact. On the contrary, he had received over $\$ 400,000$ in dividends from hydrofracking related investments in the year prior. His credibility was then much lessened. Actions like his leave the reader confused as to what is true and what is not. The fines associated with leaks and spills should be increased by a factor of 100 to 1000. The costs per infraction should be much more in line with the effects.

There has been heavy debate as to the credibility and financing of many other surveys. This is evidenced in Governor Andrew Cuomo's recent postponement of New York's final decision regarding on the continuation of the state's moratorium on hydrofracking. One main source of dialogue that is historically unbiased is university evaluation. It had appeared that Cuomo was going to lift the ban but then suddenly switched his opinion to a cautionary one after review of a four-year study. He wants more study before he extracts this resource from the land. It is important to note that the shale isn't going to disappear if not extracted immediately; it will remain trapped in the shale for many years to come. Governor Cuomo's flip-flopping indicates public figures do not always have a defensible opinion regarding safety. Often, universities take a wide look at published facts and draw conclusions as to which actions are most condonable.

Over one million oil and gas wells have been created since the late 1940s and those that have utilized enhanced recovery technologies, such as horizontal drilling and new pressurized fluids, have emerged in the past ten years make up less than $2 \%$ of all wells. Therefore, holistic consideration of impact of hydrofracking is quite small in the grand scheme of the history of drilling and wells. But its critical evaluation represents a greater potential gain than any other enhancement technology or process ever. The hardest part of the energy is designing a method and the associated mechanical equipment necessary to extract shale gas from the ground. In terms of the scale of problems in cleanup are concerned, it is expected that the monetary gains associated with the energy sector will more than outbalance the costs of finding a sustainable, clean process. Otherwise, economics will kill the process. However, the fundamental standard of valuation of human life must be preserved. That is the oath that many members of the Order of the Engineer have taken. Therefore, mitigating the effects described here should be the central focus of research groups in industrial and university settings in the future.

Hydrofracking is good for the economy and will form a large part of the energy mix that forges U.S. energy independence. It is within the reasonable financial means of the hydrofracking companies not to damage the surrounding areas such as to make them unlivable. And if they do, then they should assist with (i) the financial costs of relocating these individuals and repairing the 
land in places where it is legally required to do so and (ii) the cost of necessary direct and preventative medical care to assure that human life is not impacted. A brief list of reasonable questions yet to be answered by research are:

- How many people were or are affected in each incident?

- Which wrongdoings or sites with elevated methane concentration in drinking water can be attributed directly to hydrofracking? Since many water companies are financially independent from both governmental and HF-related companies, it makes sense for them to determine the source of the methane contamination regardless of source. If the methane source, is in a fracking region, then time-resolved studies, not necessarily performed by the water works, should compare methane concentration in plant inputs to hydrofracking activity.

- What would the dilution of these chemicals at fracking volumes over the next 20 years divided by the runoff or expected reservoir volume be? Will it be negligible because they are so large? Order of magnitude estimates of fracking water volumes over the past and next ten years should be considered.

- Legal impacts and surface rights vs. mineral rights and the concept of eminent domain.

One caveat is that Texas is not being granted an exemption; it is blatantly ignoring and claiming that the EPA does not have the power to put restrictions on its fracking activities. Clearly, all states have much to gain from fracking economically, but ignoring the environment and humans now could have severe consequences later.

\section{CONCLUSIONS}

Undeniably, hydraulic fracturing provides tremendous economic benefits as a means to extract energy from previously unattainable sources and as a way to alleviate dependence on foreign oil. However, there is intense controversy over the process stemming from the use of toxic chemicals and their proximity to sources of drinking water. The sheer number of chemical components, on the order of hundreds and possibly thousands, and their clandestine nature understandably create anxiety among the public. A large volume of literature exists which demonstrates the procedures and precautions put in place to prevent contamination of drinking water and surrounding ecosystems. But there is still concern that in the event of an accident occurring in the future, whether by negligence or human error, the repercussions would be devastating and long lasting. Although any accident reports remain tightly under wraps, there is enough anecdotal evidence of hydrofracking related catastrophes to further exacerbate public opinion.

As technology improves, many problems associated with fracking are alleviated, yet the burden remains on industry to take the appropriate actions. Again, citizens must take their concerns to their governmental representatives. Regulations have been introduced to improve the process of hydrofracking with more environmentally friendly technology and fewer harmful materials. However, this is not always enough to cause change. The restriction on diesel use executed under the Safe Water Act by the EPA is a good example wherein, due to disregard for regulation by the EPA as well as state government and insufficient enforcement, industry still uses what is essentially diesel in the fracturing process by way of loopholes. Therefore, improving regulation and even incentivizing responsible, ethical decisions are of utmost importance to improving the industry.

Justification for these regulations must come from adequate scientific experimentation. The first step to providing a basis for analysis is the disclosure of the chemicals used in hydrofracking fluid. From this, the chemicals' flow history may be tracked in order to provide compelling argument for the effects of fracking on the environment and public health. Additionally, a wider range of solutions needs to be made available for dealing with wastewater, a known source of complication. With more plentiful, cheaper options for treating wastewater, there is less inclination for oil and gas companies to act reprehensibly.

\section{REFERENCES}

1. Earthworks. Hydraulic Fracturing 101. Accessed: 24 September 2012.

2. Langston Leslie V. The Lease Pumper's Handbook (1stedn). Commission on Marginally Producing Oil and Gas Wells of Oklahoma United States 2003.

3. Drilling Sideways: A Review of Horizontal Well Technology and Its Domestic Application. Department of Energy/Energy Information Administration United States 1993.

4. Paleontological Research Institution, The Science Beneath The Surface. Marcellus Shale: Understanding Drilling Technology. Paleontological Research Institution, New York 2012.

5. Janwadkar S. Fracture Pressure Analysis of Diagnostic Pump - in Tests of Red Fork Sands in Western Oklahoma. University of Oklahoma, United States 2004.

6. Schafer Donovan D. Frack Attack: Cracking the Case against Hydraulic Fracturing. Independent Institute.org Colorado; 2012.

7. Osborn SG, et al. Methane Contamination of drinking water accompanying gas-well drilling and hydraulic fracturing. Proc Natl Acad Sci USA 2011;118:8172-8176. 
8. Helms Lynn. Horizontal Drilling. North Dakota Department of Mineral Resources, Newsletter, United States; 2008.

9. King HM. Hydraulic Fracturing of Oil \& Gas Wells Drilled in Shale 2012.

10. Clark Bobbie. US shale boom fuels growth in proppants market. ICIS News 2011.

11. Ground Water Protection Council and All Consulting. Modern shale gas development in the US: A primer. Created for Department of Energy, Office of Fossil Energy and National Energy Technology Laboratory 2009.

12. American Petroleum Institute. Freeing up energy-hydraulic fracturing: Unlocking America's natural gas resources. United States 2010.

13. Smathers J. Sand mining surges in Wisconsin. Wisconsin Watch 2011.

14. Beck T, et al. Bacteria-the Arch-Nemeses of Hydraulically Fractured Wells. Well Servicing Magazine, United States 2010.

15. Castro Dantas TN, et al. Rheological properties of a new surfactant-based fracturing gel. Colloids Surf A 2003;225:129135.

16. FracFocus: Why chemicals are used. Accessed 24 September 2012.

17. U.S. Environmental Protection Agency Permitting Guidance for Oil and Gas Hydraulic Fracturing Activities Using Diesel Fuels Draft - Underground Injection Program Guidance \#84, EPA Office of Water (4606M), Document No. EPA 816-R-12-004, United States 2012.

18. Mall Amy. EPA is now regulating hydraulic fracturing when diesel fuel is used. The Natural Resources Defense Council Expert Blog 2010.

19. Ashley A, et al. Human Health Effects of Hydraulic Fracturing Fluid BTEX Components in Drinking Water.

20. Weatherford. Water-Based Fracturing Fluids.

21. Li G, et al. Multistage hydraulic jet acid fracturing technique for horizontal wells. Petrol Explor Develop 2012;39:107-112.

22. Weatherford: Clay Control Additives.

23. Environment protection: California to Propose New Fracking Rules and Review Agency Insight of Injection Wells 2012.

24. Soraghan Mike. Narural Gas: Fracking Companies Injected 32M Gallons of Diesel House Probe Finds. E\&E News 2001.

25. Lustgarten Abrahm. Drilling Industry Says Diesel Use Was Legal. ProPublica 2011.

26. Aminto Alison, et al. Four-compartment partition model of hazardous components in hydraulic fracturing fluid additives. J Nat Gas Sci Eng 2012;7:16-21.

27. Struchtemeyer Christopher, et al. A critical assessment of the efficacy of biocides used during the hydraulic fracturing process in shale natural gas wells. Int Biodeterior Biodegradation 2012;71:15-21.

28. United States Environmental Protection Agency Office of Research and Development. Plan to Study the Potential Impacts of Hydraulic Fracturing on Drinking Water Resources 2012.

29. Ramudo A and Murphy S. Cornell University City and Regional Planning. Hydraulic Fracturing - Effects on Water Quality 2010.

30. Galusky LP Jr. Fort Worth Basin/Barnett Shale natural gas play: An assessment of present and projected fresh water use 2010.

31. Hossain $\mathrm{M}$, et al. Numerical simulation of complex fracture growth during tight reservoir stimulation by hydraulic fracturing. J Petrol Sci Eng 2008;60:86-104.

32. Waxman HA, et al. Letter to EPA Administrator Lisa Jackson regarding the use of diesel fuel in hydraulic fracturing fluids 2011.

33. Groat CG and Thomas WG. Fact-Based Regulation for Environmental Protection in Shale Gas Development. University of Texas, Austin 2012.

34. OGP. Blowout Frequencies International Association of Oil and Gas Producers. Report 434-2, 2010.

35. Kelly WR and Mattisoff G. The Effects of a Gas Well Blow Out on Groundwater Chemistry. Environ Geol Water Sci 1985;7:205213.

36. URS Corporation. Water-related issues associated with gas production in the Marcellus Shale: Additives use flowback quality and quantities regulations on-site treatment green technologies alternate water sources water well-testing. Prepared for New York State Energy Research and Development Authority 2010.

37. Pickett A. New solutions emerging to treat and recycle water used in hydraulic fracs. Am Oil Gas Reporter 2010.

38. Veil JA. Final report: Water management technologies used by Marcellus Shale gas producers. Prepared for the U.S. Depart- 
ment of Energy National Energy Technology Laboratory 2011.

39. Horn AD. Breakthrough mobile water treatment converts $75 \%$ of fracturing flowback fluid to fresh water and lowers $\mathrm{CO} 2$ emissions. Presented at the Society of Petroleum Engineers E\&P Environmental and Safety Conference 2009.

40. Arthur JD, et al. Hydraulic fracturing considerations for natural gas wells of the Marcellus Shale. Presented at The Ground Water Protection Council Annual Forum 2008.

41. West Virginia Water Research Institute. Zero discharge water management for horizontal shale gas well development: Technology status assessment. Prepared for the U.S. Department of Energy 2010.

42. The Pennsylvania Bulletin, 39. 2011.

43. Legere L. State pushes for legal end to shale wastewater discharges. The Times Tribune 2011.

44. Chemical Engineering Progress. August 2012.

45. Pappas S. Explosive Methane Gas Found in Some NY Wells. LiveScience 2012.

46. Interview with Cornell Civil \& Environmental Engineering Professor Anthony R. Ingraffeo, M.D.

47. U.S. Environmental Protection Agency Hudson River PCBS NY Document No. NYD980763841 1984.

48. MSDS sheet Source: Sigma-Aldrich.

49. Ramanujan K. Study suggests hydrofracking is killing farm animals pets. Cornell Chronicle 2012.

50. Ternes ME. Environmental Law for Chemical Engineers. Chem Eng Progress 2012;108:36-43.

51. U.S. Environmental Protection Agency Technical Program Overview: Underground Injection Control Regulations EPA Office of Water (4606) Document No. EPA 816-R-02-025; 2001.

52. U.S. Environmental Protection Agency Underground Injection Control Program 40 CPR Part 144.

53. U.S. Environmental Protection Agency Effluent Limitations Guidelines Representing the Degree of Effluent Reduction Attainable by the Application of the Best Practicable Control Technology Currently Available 40 CFR Part 435 Section 32 (40 CFW § 435.32).

54. U.S. Environmental Protection Agency Exemption of Oil and Gas Exploration and Production Wastes from Federal Hazardous Waste Regulations 2012.

55. U.S. Environment Protection Agency Mandatory Reporting of Greenhouse Gases.

56. U.S. Environmental Protection Agency Oil and Natural Gas Sector: New Source Performance Standards and National Emission Standards for Hazardous Air Pollutants Reviews 2012.

57. Institute for Energy Research. Energy Information Administration. Breaking Down the EIA 2012 Annual Energy Outlook 2012.

58. Energy Information Administration. AEO Table Browser 2012.

59. Marcellus Drilling News. How Much Does It Cost to Drill a Single Marcellus Well? \$7.6M. 2012.

60. William EH and Shaun MS. The Economic Impact of the Value Chain of a Marcellus Shale Well. University of Pittsburgh 2011.

61. New York State Department of Environmental Conservation. Fact Sheet: Economic Impacts of High-Volume Hydraulic Fracturing in New York State 2011.

62. Interstate Natural Gas Pipeline Efficiency INGAA, 2010.

63. Energy Information Administration. International Energy Outlook, 2011.

64. INGAA Foundation Inc. North America Natural Gas Midstream Infrastructure through 2035: A secure energy future, 2011.

65. Mike E. Fracture Design and Stimulation-Monitoring. Halliburton Energy Services, 2011.

66. Miesner and Leffler PenWell Co. Oil and Gas Pipelines in Nontechnical Language 2006.

67. Pipeline Knowledge \& Development INGAA. The Interstate Natural Gas Transmission System: Scale Physical Complexity and Business Model 2010.

68. Jesse FG. Booz Allen Hamilton Expanding the Shale Gas Infrastructure CEP 2012.

69. Jesse FG. Chemical Engineering Progress AICheE, August 2012.

70. Cheryl JT. The Role of Energy Pipelines and Research in the United States, 2006.

71. Robert WH. et al. Natural gas: Should fracking stop? Nature 2011. 